\title{
Diversity and morphology of abdominal glands in workers of the ant genus Myopias (Formicidae, Ponerinae)
}

\author{
Johan Billen ${ }^{\mathrm{a}, *}$, Zoë Stroobants ${ }^{\mathrm{a}}$, Tom Wenseleers ${ }^{\mathrm{a}}$, Rosli Hashim ${ }^{\mathrm{b}}$, Fuminori Ito ${ }^{\mathrm{c}}$ \\ a Zoological Institute, University of Leuven, Naamsestraat 59, B-3000 Leuven, Belgium \\ ${ }^{\mathrm{b}}$ Institute of Biological Science, University of Malaya, 50603 Kuala Lumpur, Malaysia \\ ${ }^{\text {c }}$ Faculty of Agriculture, Kagawa University, Ikenobe, Miki 761-0795, Japan
}

\section{A R T I C L E I N F O}

Article history:

Received 2 November 2012

Accepted 20 December 2012

\section{Keywords:}

Morphology

Ultrastructure

Exocrine glands

Myopias

Ponerinae

\begin{abstract}
A B S T R A C T
Histological examination of serial sections through the abdomen of workers of three species of Myopias ants revealed the presence of several exocrine glands. These include the common venom and Dufour glands as well as the pygidial gland, but also more specific sternal glands and glands associated with the sting base and the gonostyli. Two of these glands have not been reported previously among ants: one is the paired oblong plate gland, that occurs next to the oblong plate and may have a pheromonal function. The other novel gland is the paired sting shaft gland, that occurs at the dorsal side in the proximal region of the sting shaft. A remarkable characteristic of these Myopias ants is that all glands of class-3 show ducts with gradually widening internal diameter. Myopias emeryi shows a clearly more simple variety of abdominal glands than Myopias maligna and M. sp.1.
\end{abstract}

(c) 2013 Elsevier Ltd. All rights reserved.

\section{Introduction}

The exocrine system in ants is generally known to be very well developed, with an overall variety of 75 glands (Billen, 2009). This to a considerable extent is related to their social life in which a major part of the communication system relies on the action of pheromonal substances. Besides the production of pheromones, exocrine glands are also involved in the elaboration of a wide range of other substances such as digestive enzymes, venom compounds, antibiotics, lubricants, etc. (Hölldobler and Wilson, 1990; Billen and Morgan, 1998; Billen, 2011). The number of exocrine glands in individual ant species is variable, although record numbers appear to be most common among the subfamily Ponerinae: workers of Pachycondyla tridentata contain no less than 28 glands in their abdomen only (Jessen and Maschwitz, 1983). Many of these glands occur as tegumental cell clusters in various intersegmental positions (tergal, sternal, tergosternal, dorsolateral, lateroventral), where they may serve a lubricant function, especially in heavily sclerotized ants (Jessen and Maschwitz, 1983; Attygalle et al., 1996).

\footnotetext{
* Corresponding author. Tel.: +32 16323975 .

E-mail addresses: Johan.Billen@bio.kuleuven.be (J. Billen), stroobants.zoe@ gmail.com (Z. Stroobants), Tom.Wenseleers@bio.kuleuven.be (T. Wenseleers), roslihashim@um.edu.my (R. Hashim), ito@ag.kagawa-u.ac.jp (F. Ito).
}

Myopias forms small colonies with less than 100 workers in rotten wood (in rainforests) or in the soil under or between rocks (in sclerophyll woodlands). Workers are known to prey on a range of arthropods, including Collembola. They are infrequently collected and little is known of their biology. For additional details, see Willey and Brown (1983).

In the present paper, we undertook a comparative study of the abdominal glands in workers of 3 species of the genus Myopias. This genus in the tribe Ponerini comprises approx. 30 species distributed in the Oriental, Indo-Australian and Australasian regions (Bolton, 1995). Our main aim did not go to the several kinds of peripheral intersegmental glands, that all correspond to the anatomically simple system of cell clusters with ducts opening through the intersegmental membrane, but to more internal glandular formations, with main emphasis to those occurring in the sting region.

\section{Material and methods}

Colonies of Myopias emeryi (Forel, 1913), Myopias maligna (Smith, 1861) and M. sp.1 were collected in Padang, Indonesia, and Ulu Gombak, Malaysia. All three species have alate queens. $M$. emeryi is polygynous, whereas the other two are monogynous species. All three species are millipede predators. Voucher specimens of the three species are deposited in the Bogor Zoological Museum, Indonesia. 
The posterior part of worker abdomens were fixed in cold $2 \%$ glutaraldehyde, buffered at pH 7.3 with $50 \mathrm{mM}$ Na-cacodylate and $150 \mathrm{mM}$ saccharose. Postfixation was carried out in $2 \%$ osmium tetroxide in the same buffer. After dehydration in a graded acetone series, tissues were embedded in Araldite and sectioned with a Leica EM UC6 ultramicrotome. Semithin $1 \mu \mathrm{m}$ serial sections were stained with methylene blue and thionin and viewed in an Olympus BX-51 microscope, double stained $70 \mathrm{~nm}$ thin sections were examined in a Zeiss EM900 electron microscope. Material for scanning microscopy was critical point dried in a Balzers CPD 030 instrument and examined in a Philips XL30 ESEM scanning microscope. In order to obtain a better 3-dimensional understanding of the position of the various glands, a 3D-reconstruction was made from 90 cross section serial images (with an interval of $10 \mu \mathrm{m}$ ) using the Amira 5.4 programme. This included manual alignment of all section images and indication of the various glands, and visualizing the cuticular structures with the function 'volume rendering' (the result of this reconstruction is given in Fig. 1).

\section{Results and discussion}

Besides the venom gland and Dufour gland, that represent the standard sting-associated exocrine glands of all ant workers and queens, we encountered an additional five glands in the posterior part of the abdomen, that we here describe (Fig. 1). The speciesspecific occurrence and development of these glands is summarized in Table 1 . On all figures with longitudinal orientation, the anterior side is to the left.

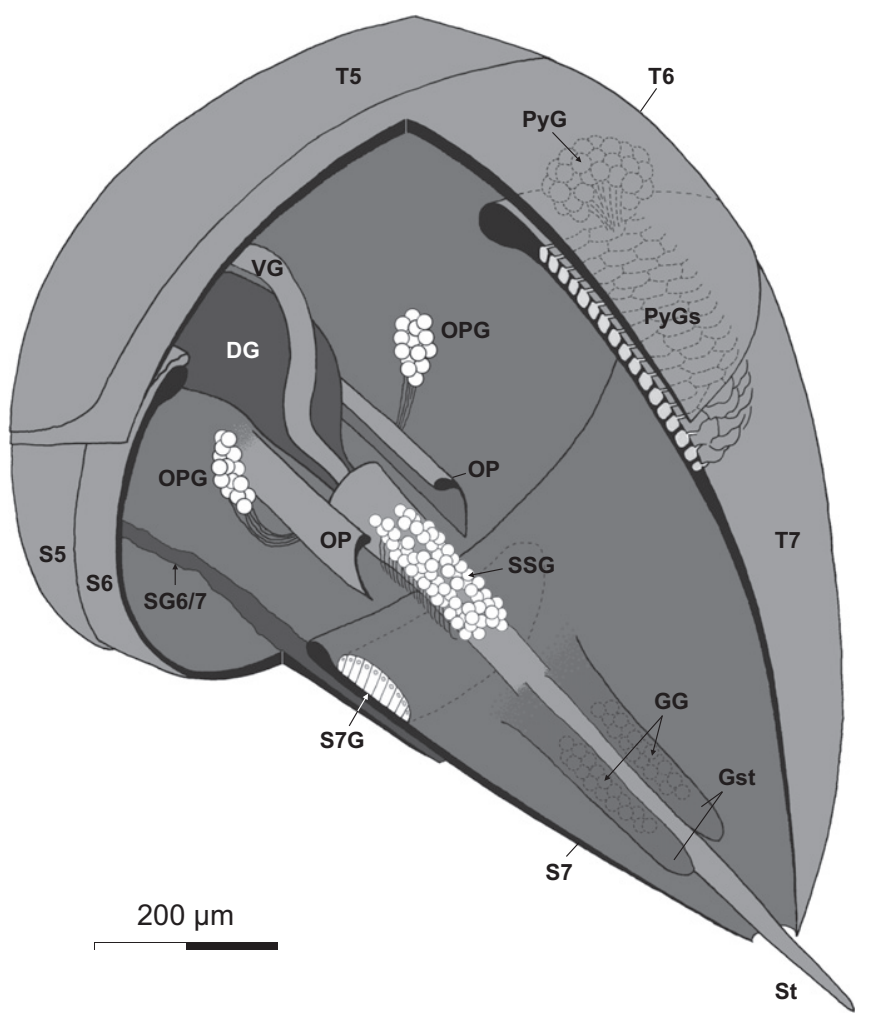

Fig. 1. Schematical representation of the abdominal tip region of M. maligna, based on 3D-reconstruction of serial sections. DG: Dufour gland, GG: gonostyli gland, Gst: gonostyli, OP: oblong plate, OPG: oblong plate gland, PyG: pygidial gland, PyGs: pygidial gland sculptured tergite area, S5, 6, 7: 5th, 6th, 7th sternite, S7G: epithelial gland 7th sternite, SG6/7: duct towards intersegmental gland between 6th and 7th sternites; SSG: sting shaft gland, st: sting, T5, 6, 7: 5th, 6th, 7th tergite, VG: venom gland.
Table 1

Occurrence and development of the abdominal glands in the Myopias species studied (+gland present, -gland absent). The venom and Dufour glands are common structures and are therefore not included in the Table.

\begin{tabular}{|c|c|c|c|c|c|c|}
\hline & $\begin{array}{l}\text { Pygidial } \\
\text { gland }\end{array}$ & $\begin{array}{l}\text { Sternal } \\
\text { gland S6/7 }\end{array}$ & $\begin{array}{l}\text { Epithelial } \\
\text { gland S7 }\end{array}$ & $\begin{array}{l}\text { Oblong plate } \\
\text { gland }\end{array}$ & $\begin{array}{l}\text { Sting shaft } \\
\text { gland }\end{array}$ & $\begin{array}{l}\text { gonostyli } \\
\text { gland }\end{array}$ \\
\hline M. emeryi & + & + & - & - & - & + \\
\hline M. maligna & + & + & + & + & + & + \\
\hline M. sp.1 & + & + & + & + & + & + \\
\hline
\end{tabular}

\subsection{Pygidial gland}

The paired pygidial gland at each side consists of a cluster of approx. 25 rounded secretory cells with a diameter around $30 \mu \mathrm{m}$, that correspond with class-3 according to the standard classification of Noirot and Quennedey (1974). Each secretory cell is associated with a duct cell that opens through the intersegmental membrane between the 6th and 7th tergites (Figs. 1 and $2 \mathrm{~B}, \mathrm{C}$ ). The ducts have a gradually increasing internal diameter, measuring $0.5 \mu \mathrm{m}$ near their junction with the secretory cell to become almost $5 \mu \mathrm{m}$ near their opening site through the intersegmental membrane (Fig. 2C). The anterior portion of the 7th tergite, adjacent to the region where the ducts open, shows a conspicuous differentiation of its cuticle with the occurrence of numerous cup-like chambers with a diameter around $10 \mu \mathrm{m}$ and a height around $20 \mu \mathrm{m}$ (Fig. 2A, B). Such cuticular cavities associated with the pygidial gland have also been described in other ants, and play a role as small storage spaces for the gland's secretion, that can be released when the cups become exposed following tergite movements. This has e.g. been reported for Pachycondyla (Termitopone) laevigata (Hölldobler and Traniello, 1980) and Megaponera foetens (Hölldobler et al., 1994), where the gland is the source of a recruitment trail pheromone. We have no information about its eventual function in the Myopias species examined here.

\subsection{Intersegmental sternal gland between sternites 6 and 7}

In the three species studied, the intersegmental membrane between the 6th and 7th sternites is deeply invaginated to form a large reservoir sac for a very conspicuous intersegmental sternal gland (Fig. 3A). A compact cluster of approx. 600-700 gland cells is situated at the ventral side of this reservoir. The cells are pearshaped with an average length of $40 \mu \mathrm{m}$ and a maximum diameter of $20 \mu \mathrm{m}$. Each secretory cell opens into the reservoir through its accompanying narrow duct cell. The ducts are arranged in bundles of approx. 10 (Fig. 3B, C). The internal diameter of the ducts again widens from $0.5 \mu \mathrm{m}$ near their junction with the secretory cell to approx. $2 \mu \mathrm{m}$ where they open into the reservoir (Fig. 3B). The reservoir wall consists of an inner cuticular layer with a thickness of 3-5 $\mu \mathrm{m}$ and a very thin squamous epithelium of hardly $1 \mu \mathrm{m}$, but without any muscular component (Fig. 3B).

The secretory cells appear to represent two cell types (Fig. 3D$\mathrm{G})$. One cell type contains an abundance of round vesicles of smooth endoplasmic reticulum, giving it a relatively pale appearance, while also a well developed Golgi apparatus and numerous mitochondria occur (Fig. 3E). The other cell type, besides a clear Golgi apparatus and numerous mitochondria, contains an abundance of tubular smooth endoplasmic reticulum, which gives it a darker appearance (Fig. 3F, G). Both cell types are characterized by a rounded nucleus and the presence of an end apparatus (Fig. 3F resp. 3G), that forms the connection with the accompanying duct cell. As cells appear to belong to either one of 

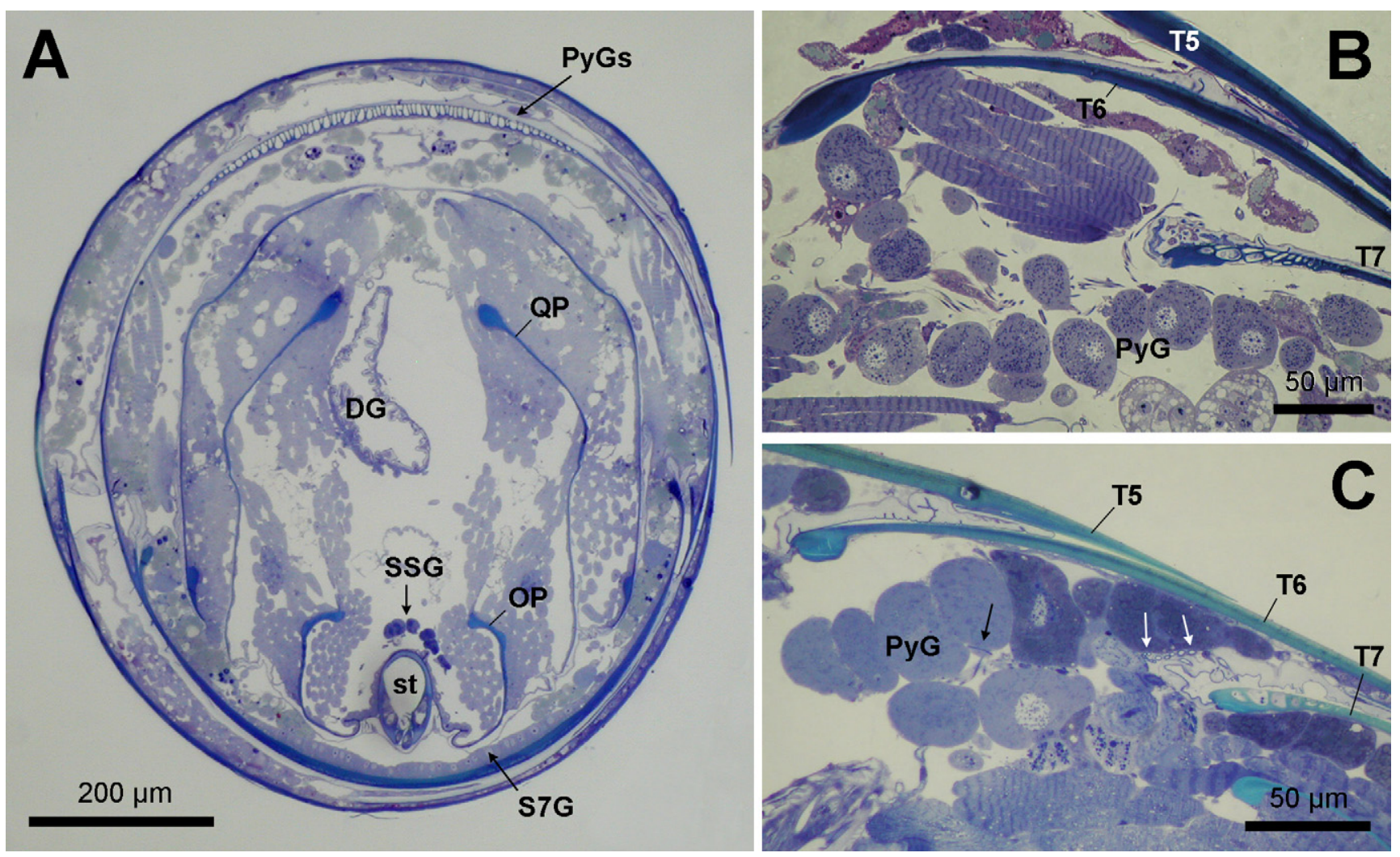

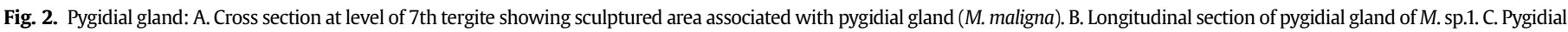

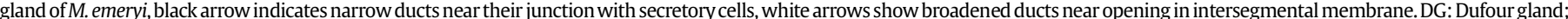

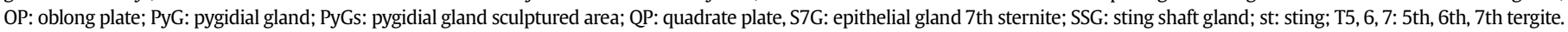

the two types without apparent intermediate stages, the two types probably represent different secretory entities rather than being different phases of a secretory cycle. A similar gland, although with much less secretory cells, has been found also in Harpegnathos saltator and some Leptogenys species, both with unknown function (Jessen et al., 1979). Preliminary behavioural experiments by one of us (FI) with M. maligna and $M$. sp. 1 showed that the secretion of this intersegmental gland is repellent towards opponents and acts as an attractant towards nestmates. For $M$. emeryi, we could not confirm whether the gland performs a similar function.

\subsection{Sternal epithelium sternite 7}

The tegumental epidermis underneath the anterior part of the 7th sternite in M. maligna and $M$. sp.1 (but not in $M$. emeryi) is differentiated into an obvious unpaired glandular epithelium (Figs. 1 and 4A). The secretory cells are lined by the tegumental cuticle, that has a thickness between 10 and $15 \mu \mathrm{m}$. In the region of the glandular epithelium, the cuticle displays very conspicuous pores, that in the lower half of the cuticle (adjacent to the epithelium) have a diameter around $0.3 \mu \mathrm{m}$ and here run in an oblique direction, while in the upper half they become more irregular and larger up to $2 \mu \mathrm{m}$, and are directed in a perpendicular direction to the cuticular surface. They open to the exterior through narrow slits that occur underneath tile-like scales that point posteriorly near the cuticular surface (Fig. 4B).

The cylindrical glandular cells have a thickness of $40-50 \mu \mathrm{m}$ with basally located rounded nuclei (Fig. 4A). Their apical cell membrane is differentiated into slender microvilli, while the lateral cell junctions in the apical region display clear interdigitations
(Fig. 4C). The cytoplasm contains numerous mitochondria and a vesicular smooth endoplasmic reticulum.

A similar glandular epithelium has also been found in a number of ponerine, ecitonine, dolichoderine and myrmicine ant species (Hölldobler and Engel, 1978), though a function has only been reported for Daceton armigerum, where it produces a shortlived trail pheromone (Hölldobler et al., 1990). As we unfortunately do not have live ants available anymore, we have no information about the eventual function of this gland in Myopias, although trail pheromone production may be possible in $M$. maligna and $M$. sp.1. For both species, clear trail following behaviour has been observed in the field, whereas no clear trail following could be seen in M. emeryi (FI, pers. obs.). This behavioural difference may be in line with the absence of this sternal epithelial gland in $M$. emeryi.

\subsection{Oblong plate gland}

A conspicuous cluster of approx. $80-100$ class- 3 cells occurs at the outer side of each oblong plate in both $M$. maligna and $M$. sp.1 (Figs. 1 and 5A, B), but is lacking in M. emeryi. The rounded cells have a diameter around $30 \mu \mathrm{m}$ and contain a spherical nucleus of $10 \mu \mathrm{m}$. The cytoplasm is characterized by a very extensive vesicular smooth endoplasmic reticulum and numerous mitochondria (Fig. 5C, D). The end apparatus shows the common arrangement with microvilli surrounding a fenestrated inner cuticular lining (Fig. 5D). The ducts associated with the secretory cells are very long, and run along the outer side of the oblong plate to open through the membrane that connects the oblong plate with the ventral sting chamber. Also these ducts display a gradually widening internal diameter from $0.5 \mu \mathrm{m}$ at their starting point in the 


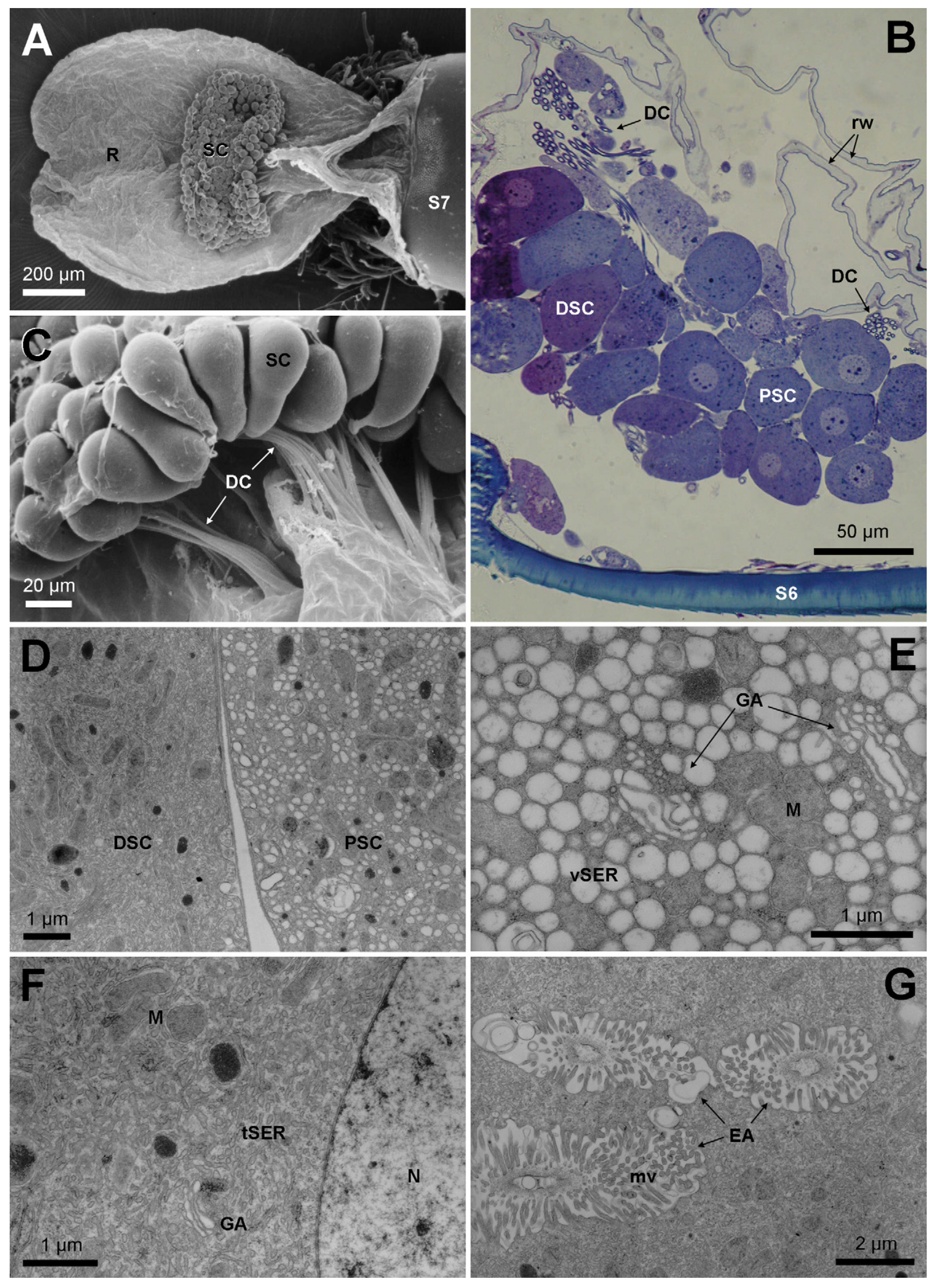


secretory cell to $2 \mu \mathrm{m}$ near their opening site (Fig. 5E). At first, the appearance of the two cell clusters reminds of the gonostyli base gland ('Stachelscheidenbasisdrüse') as described by Jessen et al. (1979, see Fig. 12), although the latter opens through the membrane that connects the oblong plate and the gonostyli - hence the name given by these authors. The opening site of the gland we describe is situated approx. $450 \mu \mathrm{m}$ anteriorly to the base of the gonostyli, and therefore cannot be considered equivalent to the gonostyli base gland described by Jessen et al. (1979). We therefore propose to designate the gland we find in Myopias as the "oblong plate gland", indicating its close association with the oblong plate. As a gland with this opening site has not been reported before, the oblong plate gland represents a novel exocrine structure for the Formicidae. Its function is not yet known, though the very extensive smooth endoplasmic reticulum indicates the secretion is non-proteinaceous, and therefore likely may have a pheromonal function.

\subsection{Sting shaft gland}

In a region of approx. $200 \mu \mathrm{m}$ along its length, the proximal part of the sting shaft is dorsally covered with an elongated cluster of approx. 60-70 round to pear-shaped class-3 cells with a length of $20-25 \mu \mathrm{m}$ and a width of $15-20 \mu \mathrm{m}$ (Fig. 1). The cytoplasm of the cells displays a high density of granular inclusions (Fig. 6A-C). On cross section, the gland may appear unpaired, although reconstruction from serial sections shows that the elongate cluster is lengthwise composed of a left and right portion. The corresponding ducts run ventrally along the outer wall of the sting shaft at either side, again with gradually widening internal diameter, to eventually open through the membrane that connects the oblong plates with the ventral sting chamber (Fig. 6A). This opening site reminds that of the sting chamber gland ('Stachelkammerdrüse') described by Jessen et al. (1979, see Fig. 14), although these cells occur as two small clearly lateral clusters, that are not associated with the sting shaft at all. The gland we here describe in Myopias, therefore, represents another novel gland for the Formicidae, for which we suggest the name "sting shaft gland". It occurs in $M$. maligna and $M$. sp.1, but is lacking in M. emeryi. The function for the time being remains unknown, although the abundance of granular inclusions in the cytoplasm may correspond with the elaboration of a proteinaceous, and hence non-pheromonal secretion. Lack of study material unfortunately prevented us to examine the ultrastructural features of this gland, which would be needed for a more precise characterization of the secretory inclusions.

\subsection{Gonostyli gland}

Inside the greater portion of each of the gonostyli of the three species, we found $30-40$ round to ovoid class-3 secretory cells with

Fig. 3. Sternal gland between 6th and 7th sternite: A. Ventral view scanning micrograph of large reservoir sac and cluster of secretory cells ( $M$. sp.1). B. Longitudinal section of intersegmental sternal gland showing cluster of secretory cells, ducts with gradually increasing diameter and wrinkled reservoir (M. sp.1). C. Detail scanning micrograph of secretory cell cluster (M. sp.1). D. Electron micrograph of intersegmental sternal gland showing two types of secretory cells (M. maligna). E. Detail of pale secretory cell with abundant vesicular smooth endoplasmic reticulum (M. maligna). F. Detail of dark secretory cell with abundant tubular smooth endoplasmic reticulum (M. maligna). G. End apparatus in dark secretory cell (M. maligna). DC: duct cells; DSC: dark secretory cells; EA: end apparatus; GA: Golgi apparatus; M: mitochondria, mv: microvilli; N: nucleus; PSC: pale secretory cells; R: reservoir; rw: reservoir wall; S6: 6th sternite; SC: secretory cells; tSER: tubular smooth endoplasmic reticulum; vSER: vesicular smooth endoplasmic reticulum.
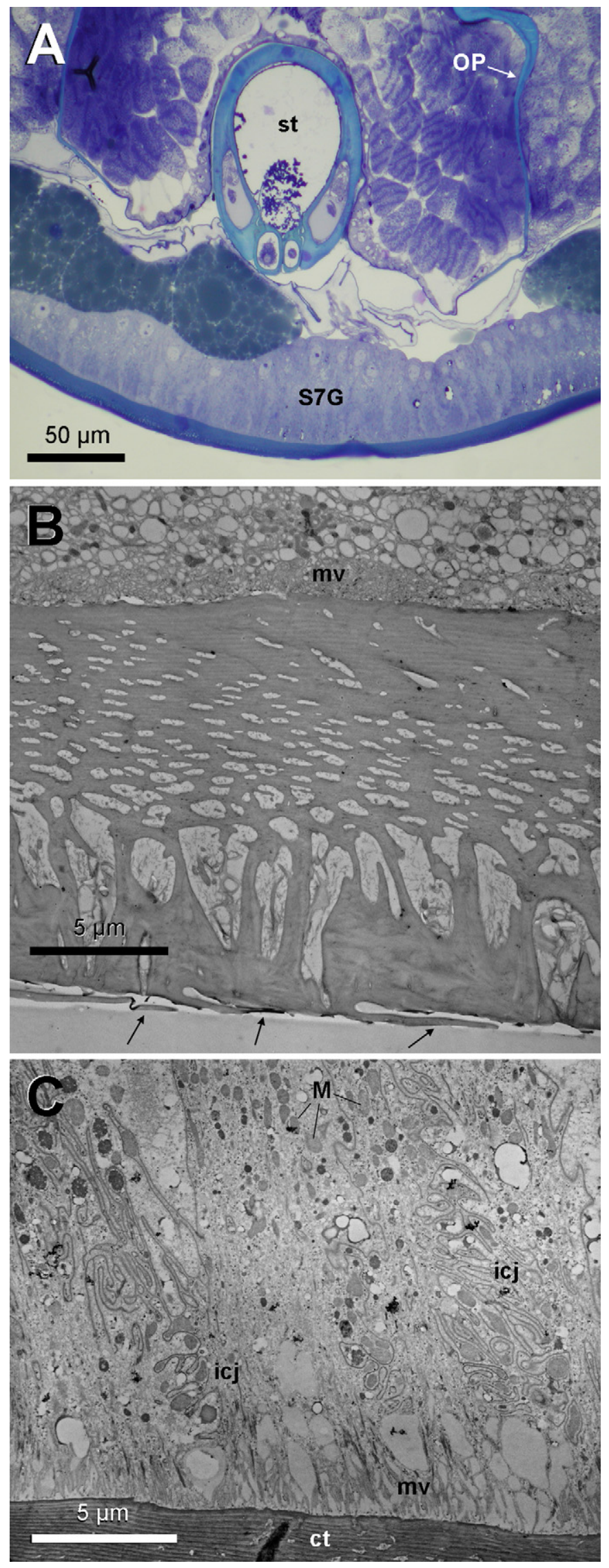

Fig. 4. Epithelial gland 7th sternite: A. Cross section through anterior part of 7th sternite (M. maligna). B. Ultrastructure of cuticle overlying glandular epithelium, showing elaborate pore system (M. maligna). C. Electron micrograph of apical part of glandular epithelium (M. sp.1). ct: cuticle, icj: intercellular junction; M: mitochondria, mv: microvilli; OP: oblong plate; S7G: epithelial gland 7th sternite; st: sting. 

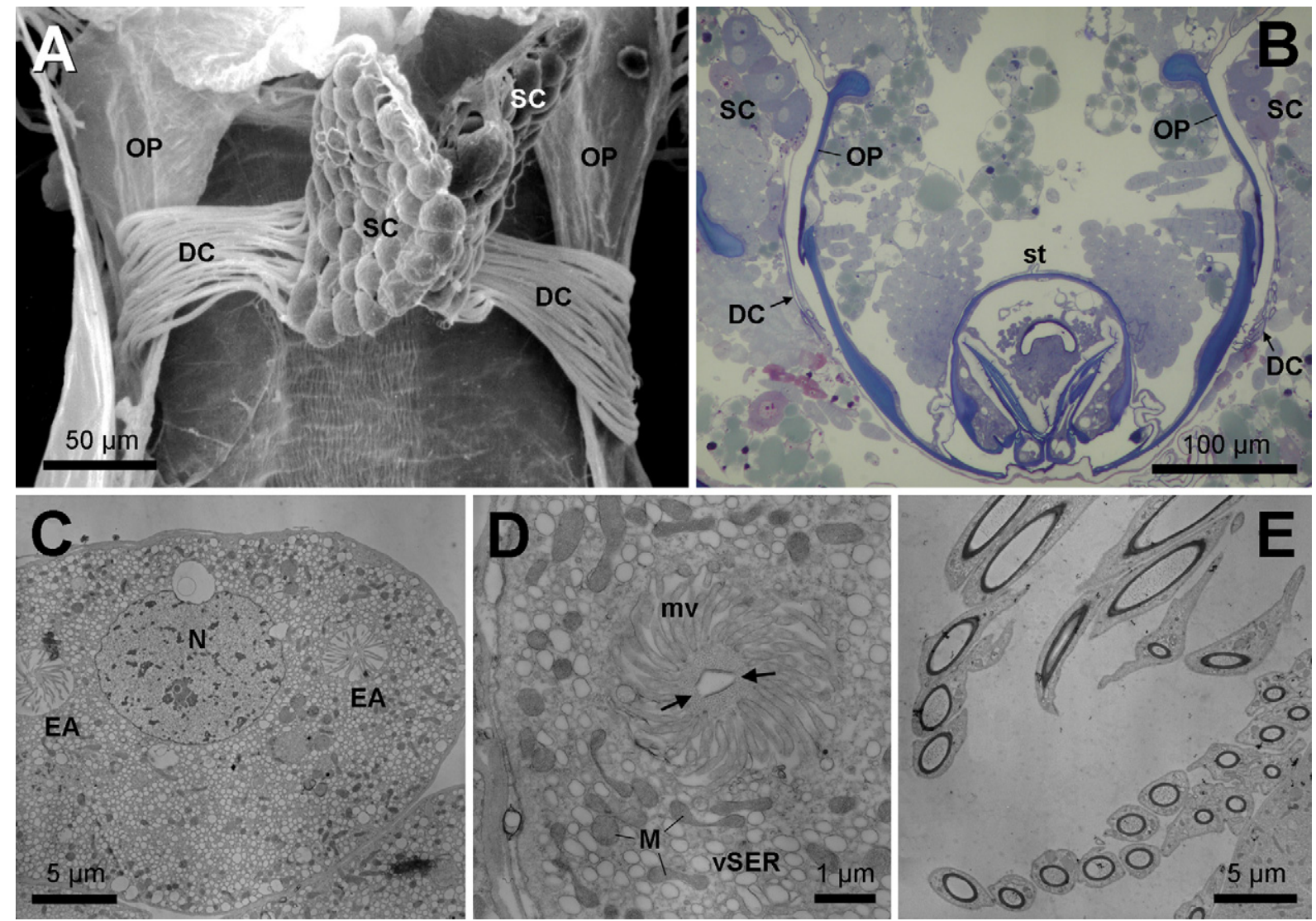

Fig. 5. Oblong plate gland: A. Dorsal view scanning micrograph of both oblong plates with the conspicuous novel oblong plate gland and its long lateral ducts (both cell clusters probably stick to each other due to tissue preparation; M. sp.1). B. Cross section showing position of oblong plate gland; note very long duct cells (M. maligna). C. Electron micrograph of secretory cell with round nucleus (M. maligna). D. Detail of secretory cell, showing vesicular smooth endoplasmic reticulum. Arrows indicate interrupted cuticular lining of end apparatus (M. maligna). E. Electron micrograph of duct cells, clearly showing variation in diameter (M. sp.1). DC: duct cells; EA: end apparatus; M: mitochondria, mv: microvilli; N: nucleus; OP: oblong plate; SC: secretory cells; st: sting.
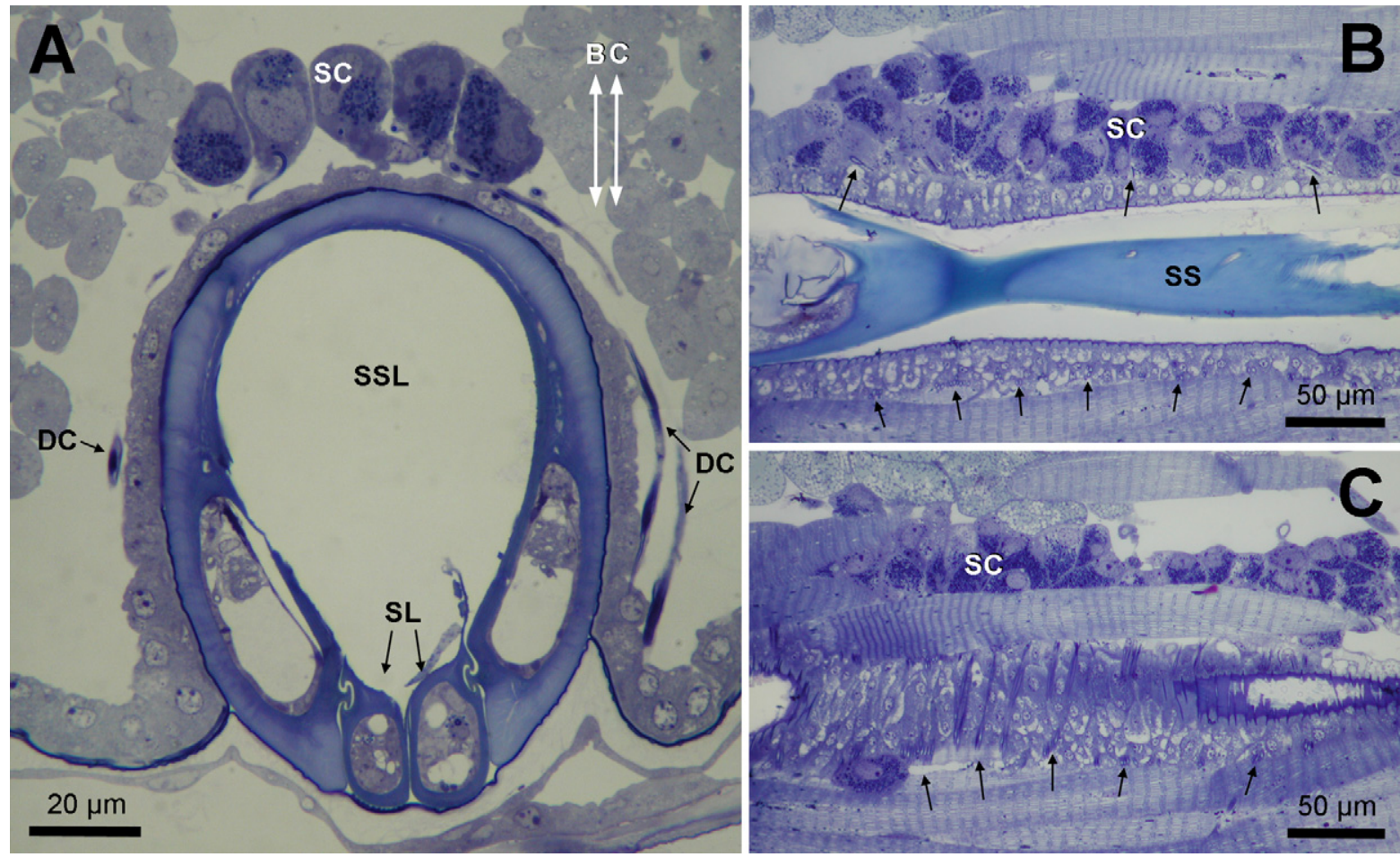

Fig. 6. Sting shaft gland: A. Cross section through proximal part of sting shaft, showing secretory cells and duct cells of the novel sting shaft gland (M. maligna). B and C. Longitudinal sections through proximal part of sting shaft at level indicated by white double arrows in A. Arrows indicate ducts (M. sp.1). DC: duct cells; SC: secretory cells; SL: sting lancets; SS: sting shaft; SSL: sting shaft lumen; st: sting . 

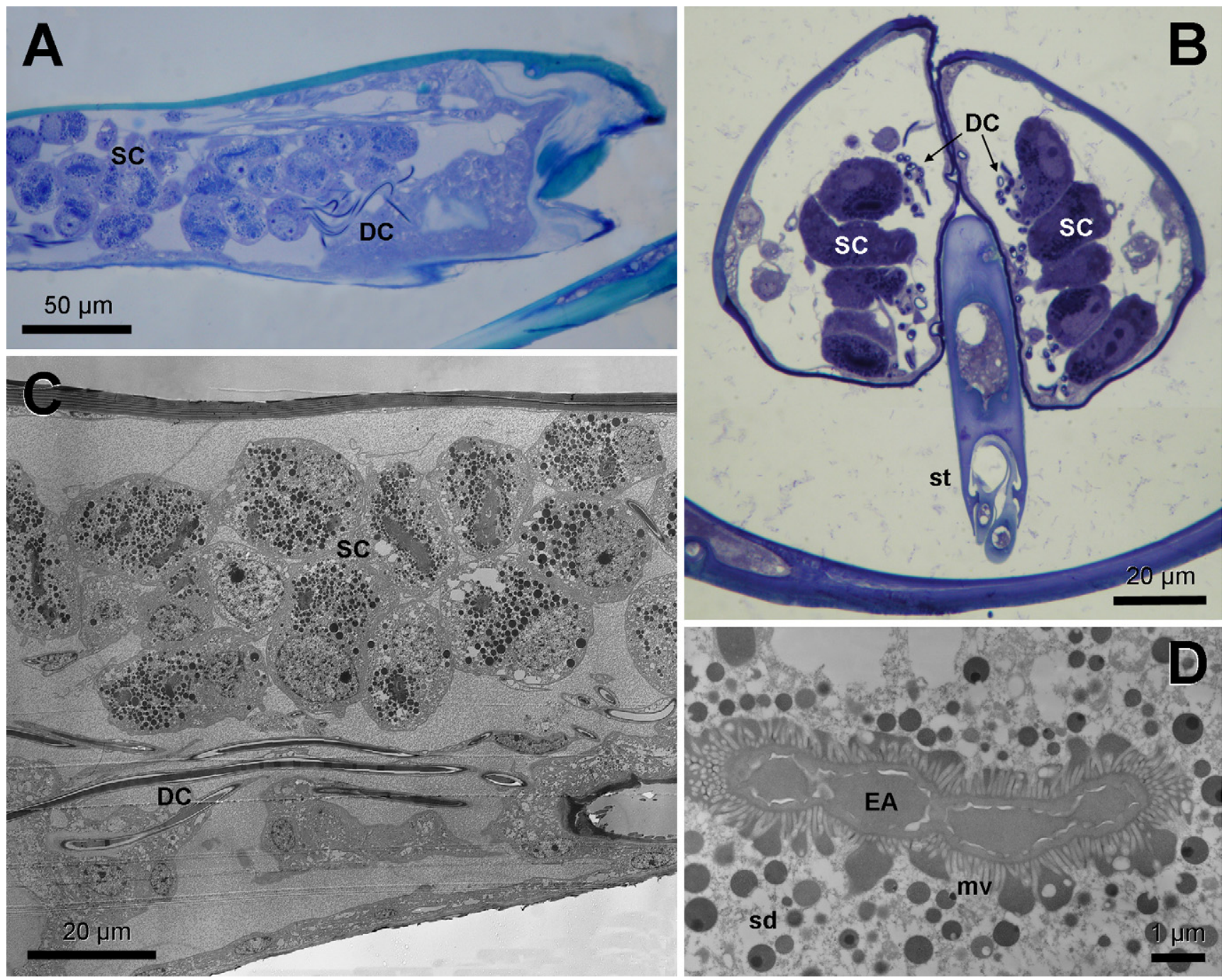

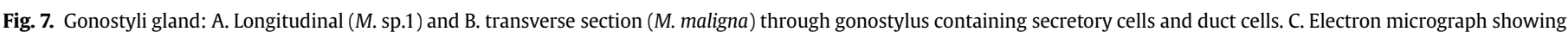

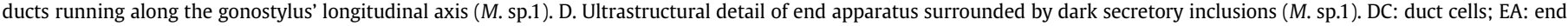
apparatus; mv: microvilli; SC: secretory cells; sd: secretory droplets; st: sting.

a diameter of approx. $20 \mu \mathrm{m}$ (Figs. 1 and 7A, B). The ducts run along the longitudinal axis of the gonostyli (Fig. 7C), and open through their inner wall adjoining the sting (Fig. 7B). Also for this gland, the ducts are characterized by their internal diameter that gradually widens from approx. 0.5 up to $2 \mu \mathrm{m}$ (Fig. 7B). The cytoplasm contains an abundance of electron-dense granular inclusions with a diameter between 0.2 and $0.5 \mu \mathrm{m}$, that accumulate around the end apparatus (Fig. 7D). These inclusions may represent protein granules. Literature mentions about two kinds of gonostylar glands, one formed by epithelial class- 1 cells and the other by class- 3 cells, of which the corresponding ducts open at the side directed towards the sting. These glands have been described in several ponerine, myrmeciine and myrmicine species (Janet, 1898; Hölldobler and Engel, 1978; Jessen et al., 1979; Jessen and Maschwitz, 1983). The existence of epithelial gonostyli glands has also been listed by Cassier et al. (1994) in honeybee workers, where it induces alarm behaviour.

\section{Conclusion}

Our survey of the exocrine glands in the posterior abdominal region of Myopias provides another example of the high variety of glands in ponerine ants, as was already illustrated by Jessen et al.
(1979) and Jessen and Maschwitz (1983). Two glands are novel additions to the exocrine repertoire of ants, their function remains as yet unknown, but can hopefully be documented in future. A remarkable feature of all class-3 glands (pygidial gland, sternal gland between 6th and 7th sternite, oblong plate gland, sting shaft gland, gonostyli gland) is that the diameter of the ducts shows a gradually increasing diameter, starting from approx. $0.5 \mu \mathrm{m}$ at their starting point near the secretory cell up to $2-5 \mu \mathrm{m}$ near their opening site. We also checked the mandibular gland (in the head) and the metapleural gland (in the thorax), in which we equally found this characteristic of widening ducts. Although the functional significance of this feature is not clear, it is in contrast with the very uniform size of approx. $0.5-1 \mu \mathrm{m}$ that is the standard diameter of class- 3 exocrine glands in insects. Another remarkable observation is that $M$. emeryi shows a clearly more simplified exocrine system in comparison to the other species examined. This may be in line with the smaller colony size as well as the more simplified communication system in $M$. emeryi, in which, e.g., clear trail following behaviour could not be observed, whereas the two other species do follow pheromone trails. M. maligna and $M$. sp.1 moreover are characterized by a special smell, which probably also reflects their more elaborate exocrine system compared to M. emeryi. 


\section{Acknowledgements}

This article is dedicated to the memory of Els Plaum, who made thousands of high quality sections for electron microscopy at the onset of our morphological research. We are very grateful to An Vandoren, Koen Collart and Julien Cillis for their skilful help in tissue preparation for microscopy, and to Yuji Kitagawa for generously offering workers of Myopias maligna. This research was supported through grant $\mathrm{Nr}$ OT/2001/24 from the KULeuven Research Fund and grants $\mathrm{Nr}$ 08041141, 11691130 and 14405036 for Overseas Research from the Japanese Ministry of Education, Science and Culture.

\section{References}

Attygalle, A.B., Jessen, K., Bestmann, H.-J., Buschinger, A., Maschwitz, U., 1996. Oily substances from gastral intersegmental glands of the ant Pachycondyla tridentata (Ponerinae): lack of pheromone function in tandem running and antibiotic effects but further evidence for lubricative function. Chemoecology 7, $8-12$

Billen, J., 2009. Diversity and morphology of exocrine glands in ants. In: Proc. XIX Simp. Mirmecologia, Ouro Preto, Brasil, 17-21 Nov. 2009, pp. 1-6.

Billen, J., 2011. Exocrine glands and their key function in the communication system of social insects. Formosan Entomology 31, 75-84.

Billen, J., Morgan, E.D., 1998. Pheromone communication in social insects - sources and secretions. In: Vander Meer, R.K., Breed, M.D., Winston, M.L., Espelie, K.E.
(Eds.), Pheromone Communication in Social Insects: Ants, Wasps, Bees, and Termites. Westview Press, Boulder, Oxford, pp. 3-33.

Bolton, B., 1995. A New General Catalogue of the Ants of the World. Harvard University Press, Cambridge, Mass., London.

Cassier, P., Tel-Zur, D., Lensky, Y., 1994. The sting sheaths of honey bee workers (Apis mellifera L.): structure and alarm pheromone secretion. Journal of Insect Physiology 40, 23-32.

Hölldobler, B., Engel, H., 1978. Tergal and sternal glands in ants. Psyche 85, 285329.

Hölldobler, B., Traniello, J.F.A., 1980. The pygidial gland and chemical recruitment communication in Pachycondyla (= Termitopone) laevigata. Journal of Chemical Ecology 6, 883-893.

Hölldobler, B., Wilson, E.O., 1990. The Ants. Harvard University Press, Cambridge Mass.

Hölldobler, B., Palmer, J.M., Moffett, M.W., 1990. Chemical communication in the dacetine ant Daceton armigerum (Hymenoptera: Formicidae). Journal of Chemical Ecology 16, 1207-1219.

Hölldobler, B., Braun, U., Gronenberg, W., Kirchner, W.H., Peeters, C., 1994. Trail communication in the ant Megaponera foetens (Fabr.) (Formicidae, Ponerinae) Journal of Insect Physiology 7, 585-593.

Janet, C., 1898. Etudes sur les fourmis, les guêpes et les abeilles. Note 17: système glandulaire tégumentaire de la Myrmica rubra. In: Observations diverses sur les fourmis. Carré \& Naud, Paris, p. 30.

Jessen, K., Maschwitz, U., 1983. Abdominaldrüsen bei Pachycondyla tridentata (Smith): Formicidae, Ponerinae. Insectes Sociaux 30, 123-133.

Jessen, K., Maschwitz, U., Hahn, M., 1979. Neue Abdominaldrüsen bei Ameisen. I. Ponerini (Formicidae, Ponerinae). Zoomorphologie 94, 49-66.

Noirot, C., Quennedey, A., 1974. Fine structure of insect epidermal glands. Annua Review of Entomology 19, 61-80.

Willey, R.B., Brown, W.L., 1983. New species of the ant genus Myopias. Psyche 90, 249-285. 